\title{
Application of acidic accelerator for production of pure hydrogen from $\mathrm{NaBH}_{4}$
}

\author{
Wameath S. Abdul-Majeed • Muhammad T. Arslan • \\ William B. Zimmerman
}

Received: 2 July 2013/Accepted: 4 April 2014/Published online: 30 April 2014

(C) The Author(s) 2014. This article is published with open access at Springerlink.com

\begin{abstract}
Feasibility of using hydrochloric acid $(\mathrm{HCl})$ as an accelerator for onboard production of hydrogen from sodium borohydride $\left(\mathrm{NaBH}_{4}\right)$ is investigated. The aim was to examine process efficiency, hydrogen purity and process controllability which concurs onboard 2015 hydrogen storage target $(5.5 \mathrm{wt} \%)$ for vehicular fuel cell system application. Results showed that a highest yield and controllable hydrogen production rate are achievable upon adopting onboard reaction of $\mathrm{HCl}(3 \mathrm{M})$ and an aqueous alkaline solution of $30 \% \mathrm{NaBH}_{4}$ via a T-junction and applying a gas-liquid separation of two stages. Cost evaluation and product stream analysis have demonstrated an exceptional performance for the examined scheme and relevancy to be adopted for feeding vehicular electrochemical fuel cell systems.
\end{abstract}

Keywords Fuel cells - Solid state hydrogen storage . Sodium borohydride

\section{Introduction}

In view of the fact that hydrogen is the key energy carrier, interests are increasingly exhibited to utilize it as a fuel for internal combustion engines and electrochemical fuel cells. Nevertheless, technical issues such as storage and transportation are still big barriers against its wider use [1].

Hydrogen can be stored physically as a compressed gas or in liquid form. Nonetheless, pressures required for

W. S. Abdul-Majeed ( $₫) \cdot$ M. T. Arslan · W. B. Zimmerman Department of Chemical and Biological Engineering, The University of Sheffield, Sheffield S1 3JD, UK e-mail: wameath@yahoo.com compression are too high because of its low boiling and melting points. Thus, very few materials, so far, can handle this much pressure. Hence, compressed hydrogen is not user friendly due to the risk of leakage and explosion hazards, which limits its commercial availability worldwide [2]. On the other hand, fuels such as methanol, ethanol and methane can be a source of hydrogen. However, operational requirements (e.g. high temperature) are restricting its economic use for fuel cell applications [3]. Alternatively, hydrogen can be stored chemically in a solid state medium such as metal and chemical hydrides which are considered to have a great potential to store hydrogen effectively and safely under standard conditions [4]. Principally, chemical hydrides are more advantageous compared with metal hydrides in terms of hydrogen content, storage capacity and operational requirements [5]. As a safe onboard hydrogen storage candidate, sodium borohydride $\left(\mathrm{NaBH}_{4}\right)$ has gained the highest gravimetric/volumetric hydrogen storage capacity over other chemical hydrides (theoretically $=10.8 \mathrm{wt} \%$ ) as well as other features such as nonflammable, non-toxic chemical and its stability in dry and alkaline conditions.

Although voluminous literatures showed a significance of applying solid state hydrogen generation system for vehicular portable applications, it has been given a No-Go recommendation by the US Department of Energy (DOE) due to several technical and economical issues. Reasons were reported to be mainly related to a difficulty in recycling meta-borates to borohydride and incapability to achieve system storage targets [6].

Hydrogen can be generated from sodium borohydride through catalytic hydrolysis reaction at low temperature, in which four moles of hydrogen are released in addition to the sodium meta-borate as by-products [7, 8]. 
$\mathrm{NaBH}_{4}+2 \mathrm{H}_{2} \mathrm{O} \stackrel{\text { Catalyst }}{\longrightarrow} 4 \mathrm{H}_{2}+\mathrm{NaBO}_{2(\mathrm{aq})}+$ Heat

Using sodium borohydride at $10-15 \mathrm{wt} \%$ was considered to be optimal by several researchers [9], as it reacts very slowly with water. Therefore, it can be stopped readily by addition of alkaline medium (e.g. sodium hydroxide) or accelerated by adding acids or applying catalysts (e.g. metals of both noble and non-noble nature) [10]. Although a catalyst (e.g. RU) was reported to be able, theoretically, to provide up to 100,000 turnovers, nonetheless, practical issues such as onboard regeneration were found to be a big barrier against its industrial adaptation. Hence, higher hydrogen yield and conversion efficiency are better achieved when applying acid catalysts. This is due to the fact that all reacting species $\left(\mathrm{H}^{+}\right)$are completely consumed and therefore the hydrogen generation rate is controlled precisely through addition of acid, which is highly requested for onboard applications. The acidic scheme is illustrated by the following reaction $[9,10]$.

$\mathrm{NaBH}_{4}+3 \mathrm{H}_{2} \mathrm{O}+\mathrm{HCl} \rightarrow 4 \mathrm{H}_{2}+\mathrm{H}_{3} \mathrm{BO}_{3}+\mathrm{NaCl}$

Utilization of acid accelerators for $\mathrm{NaBH}_{4}$ hydrogen generation system was first tested in 1950s, in which more than 20 acids were assessed (e.g. oxalic acid, citric acid, boric acid, formic acid and many others). The results showed that the reaction upon adding these acids was very violent and vigorous; hence it was decided to choose a relatively safer option [7]. Until beginning of 2000, acids were found unsuccessful accelerators for $\mathrm{NaBH}_{4}$ hydrolysis due to safety issues. However, recent research endeavour showed that some acids can be used as potential direct accelerators or indirect activator for heterogeneous catalysts (Xu et al. 2008 and [11, 12]). Moreover, there were few acids suggested by [13] which could be used as a single-use accelerator for a portable $\mathrm{NaBH}_{4}$ hydrogen generation system. These acids include hydrochloric acid, sulphuric acid, nitric acid, phosphoric acid, formic acid and acetic acid. They also found that some acids possess the ability to delay formation of hydrated by-products, via shifting $\mathrm{pH}$ to lower values, and thereby $\mathrm{NaBH}_{4}$ hydrolysis could be improved [3].

Main advantages of the acidic hydrolysis scheme are: (1) acid accelerators can be stored as an aqueous solution of variable concentrations, (2) the scheme can be performed at room temperature, (3) sodium meta-borate produced was shown to be barely toxic and environmental friendly, which makes it possible to be recycled, (4) high purity hydrogen gas can be obtained, which suits highly sensitive fuel cells such as Proton Exchange Membrane Fuel Cell, (5) upon using acid accelerator, formation and crystallization of by-products is delayed or inhibited, and (6) Practically, even with 1:1 $\left(\mathrm{HCl}: \mathrm{NaBH}_{4}\right.$ stoichiometric ratios), applying acidic scheme is believed to be cost- effective option for onboard fuel cell applications, taking into consideration the operational troublesome for metal catalysts (e.g. Ruthenium, $\mathrm{CoCl}_{2}$ ). Consequently, acid accelerators may act effectively for onboard fuel cell applications should a sophisticated scenario defines the optimal operating conditions becomes applicable.

It is worth noting that an acidic hydrolysis scheme was explored with less attention compared with catalytic schemes, therefore it is required to conduct further researches toward better system understanding and to measure feasibility for a portable fuel cell application.

In a previous work [14], we investigated the performance of liquid nitrogen cold trap for purifying a hydrogen stream generated from catalytic and acidic decompositions of $\mathrm{NaBH}_{4}$. In the current research, an increase of hydrogen yield is attempted by applying a higher concentration of acidic accelerator and $\mathrm{NaBH}_{4}$ concentration up to $30 \mathrm{wt} \%$ in an aqueous alkaline solution. The paper is arranged in four parts, in which an experimental description, results and discussion and conclusions are presented in the following sections.

\section{Methods}

An experimental setup illustrated in Fig. 1 was applied in the experiments. A simple hydrogen generation system was designed to generate hydrogen at a controllable rate and to obtain desired objectives. The main apparatus consisted of fuel solution containers, followed by two peristaltic pumps, a tee connection, product collector and a gas-liquid separator. $\mathrm{HCl}$ and $\mathrm{NaBH}_{4}$ streams made a contact through a Tee connection leading to an instantaneous hydrogen generation along with by-products and excess water. Sometimes, excess $\mathrm{HCl}$ was also observed in the product solution. Product solution was collected in the product collector and the hydrogen stream was passed through the gas-liquid separator where the liquid phase was separated and pure hydrogen gas was released from the system. Peristaltic pumps of a single channel driven by AC motor were used (Williamson manufacturing Co., UK), in which a pump of $0.97 \mathrm{ml} / \mathrm{min}$ and another of $1.25 \mathrm{ml} / \mathrm{min}$ calibrated flow rate or vice versa were applied for feeding $\mathrm{NaBH}_{4}$ and $\mathrm{HCl}$ solutions, respectively. In a later stage, another peristaltic pump of $1.03 \mathrm{ml} / \mathrm{min}$ was applied for $\mathrm{NaBH}_{4}$ solution feeding. Silicone tubing (1.6 mm ID) was used throughout the setup for liquid and gas transportation. Two glass containers of $80 \mathrm{ml}$ were applied as two stages gas-liquid separator. The aim was to purify generated hydrogen stream from moisture and accompanied alkaline mist based on a difference in density. Hydrogen generation rate was calculated using a water displacement method through a $250 \mathrm{ml}$ glass cylinder. Samples of the generated 
Fig. 1 Experimentation system Tubing \& Direction of flow of solution

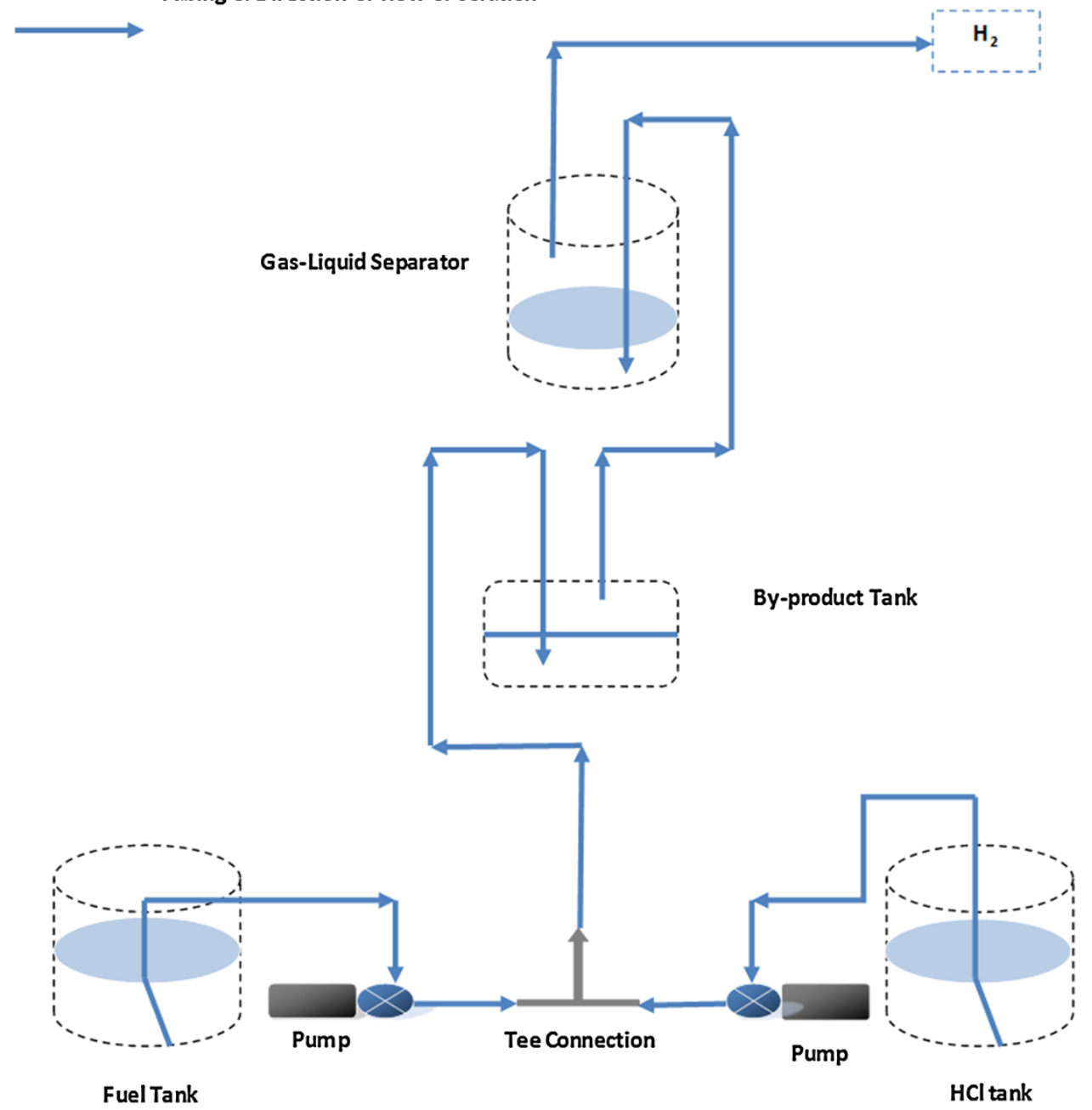

hydrogen after second separation stage were collected using a gas sampler and analysed through a gas chromatography system (Varian CP-3800). Sodium borohydride $(98 \%)$ and sodium hydroxide (97\%) purchased from Sigma Aldrich in addition to hydrochloric acid (36\%) from Fisher Scientific were used in the experiments.

\section{Results and discussion}

Two parallel case studies were conducted in this research. In the first study, use of $\mathrm{HCl}$ as an accelerator was investigated and different associated parameters were examined. Second study was devoted to examine feasibility of generating $5.5 \mathrm{wt} \%$ of hydrogen that concurs US DOE 2015 storage targets. Samples of experimental results are shown in Tables 1, 2, and 3 .

A value of $1 \mathrm{wt} \% \mathrm{NaOH}$ was adopted in all experiments in both studied cases for fuel $\left(\mathrm{NaBH}_{4}\right)$ solution stabilization, since it has been proven to be optimal concentration [14].
It is worth noting that a $10-15 \mathrm{wt} \% \mathrm{NaBH}_{4}$ and $1-6 \mathrm{M}$ $\mathrm{HCl}$ were indicated in the literature as a workable range for economical hydrogen generation from $\mathrm{NaBH}_{4}$ catalytic scheme. However, it depends on solutions flow rate and catalyst type. In the current work, a range of fuel solution $\left(\mathrm{NaBH}_{4} 10,15,20\right.$ and $\left.25 \mathrm{wt} \%\right)$ along with 3 and $4 \mathrm{M}$ of $\mathrm{HCl}$ solution were examined in the first case study. These values were selected upon conducting pre-experiments during system pre-commissioning.

A water displacement method was used for measuring generated hydrogen stream rate as it is a pioneer of gas measurement. Measured value was an average of five replicates at $1 \mathrm{~min}$ interval between them. The standard deviation of five replicates was $<2$ in all experiments, which indicates a fair estimation. Figure 2 illustrates these results. Hydrogen density was calculated to be $0.0993 \mathrm{~kg} \mathrm{~m}^{-3}$, based on the system operational conditions (fuel solution and acidic solution entering at approximately $20{ }^{\circ} \mathrm{C}$ and 1.2 barg) and using the ideal gas law.

Zali et al. [15] presented the hydrolysis of $\mathrm{NaBH}_{4}$ in an acidic solution as follows: 
Table 1 Experimental results- $10 \% \mathrm{NaBH}_{4}$ and $3 \mathrm{M} \mathrm{HCl}$

\begin{tabular}{|c|c|c|c|}
\hline \multirow[t]{2}{*}{ Amount of $\mathrm{NaBH}_{4}(\mathrm{~g})$} & 5.6 & \multirow[b]{2}{*}{ Solution wt $\%$} & \multirow[b]{2}{*}{10} \\
\hline & & & \\
\hline Amount of $\mathrm{NaOH}(\mathrm{g})$ & 0.6 & & \\
\hline \multirow[t]{2}{*}{ Mass of solution (g) } & 55.6 & & \\
\hline & & Density of solution $(\mathrm{g} / \mathrm{ml})$ & 1.04905 \\
\hline Volume of solution (ml) & 53 & & \\
\hline Flow rate of $\mathrm{NaBH}_{4}(\mathrm{ml} / \mathrm{min})$ & 0.971 & Flow rate of $\mathrm{HCl}(\mathrm{ml} / \mathrm{min})$ & 1.25 \\
\hline Hydrogen generation rate & $\begin{array}{l}\text { Volume of } \\
\mathrm{H}_{2}(\mathrm{ml})\end{array}$ & Seconds & $\mathrm{ml} / \mathrm{min}$ \\
\hline Reading 1 & 250 & 55.47 & 270.4 \\
\hline Reading 2 & 250 & 56.25 & 266.6 \\
\hline Reading 3 & 250 & 55.97 & 268.0 \\
\hline Reading 4 & 250 & 56.31 & 266.3 \\
\hline Reading 5 & 250 & 55.97 & 268.0 \\
\hline Temp K & 305 & Mean HGR $\mathrm{ml} / \mathrm{min}$ & 267.8 \\
\hline \multicolumn{4}{|l|}{ Using $1 \mathrm{~min}$ basis } \\
\hline \multicolumn{2}{|c|}{ Mass flow rate (density $\times$ flow rate of $\mathrm{NaBH}_{4}$ ) } & 1.0186 & \\
\hline \multicolumn{2}{|c|}{ Mass of $\mathrm{NaBH}_{4}\left(\right.$ conc of $\mathrm{NaBH}_{4} \times$ mass flow rate $)$} & 0.1019 & \\
\hline \multicolumn{2}{|c|}{ Mole of $\mathrm{NaBH}_{4}$ (mass of $\mathrm{NaBH}_{4} / 37.8$ ) } & 0.0027 & \\
\hline \multicolumn{2}{|c|}{ Mole of $\mathrm{H}_{2}\left(\right.$ mole of $\left.\mathrm{NaBH}_{4} \times 4\right)$} & 0.0108 & \\
\hline \multicolumn{2}{|c|}{ Theoretical volume of hydrogen $(\mathrm{ml} / \mathrm{min})$} & 269.8 & \\
\hline \multicolumn{2}{|c|}{ Actual volume of hydrogen (ml/min) } & 267.8 & \\
\hline \multicolumn{2}{|l|}{ Conversion efficiency } & $99 \%$ & \\
\hline \multicolumn{2}{|l|}{ Molar HGR } & 0.0106 & \\
\hline \multicolumn{2}{|l|}{ Ampere (A) } & 34.2005 & \\
\hline \multicolumn{2}{|l|}{ Watt (W) } & 23.94 & \\
\hline \multicolumn{2}{|l|}{ Product $\mathrm{pH}$} & 2-acidic & \\
\hline
\end{tabular}

$\mathrm{BH}_{4}^{-}+\mathrm{H}^{+}+3 \mathrm{H}_{2} \mathrm{O} \rightarrow \mathrm{B}(\mathrm{OH})_{3}+4 \mathrm{H}_{2}$

Since the acidic hydrolysis is a relatively homogeneous process (due to a controlled contact of two streams) and excess water is available in the bulk, concentrations of water and hydrogen are considered constant. Hence, the kinetic equation of $\mathrm{NaBH}_{4}$ acidic hydrolysis is presented by the following equation:

$r=\frac{\mathrm{d}\left[\mathrm{NaBH}_{4}\right]}{\mathrm{d} t}=k\left[\mathrm{NaBH}_{4}\right]$

The authors [15] reported that a pseudo-first order kinetic model fits the hydrogen generation from $\mathrm{NaBH}_{4}$ quite well. They concluded that a rate constant $(k)$ of $0.003 \mathrm{~s}^{-1}$ well describes the hydrolysis reaction (acidic scheme) with no catalyst. Accordingly, the activation energy of the acidic hydrolysis can be estimated from Arrhenius equation, considering a rate constant of $0.003 \mathrm{~s}^{-1}$ for a reaction bulk at $20{ }^{\circ} \mathrm{C}$ (at the contact point of the streams), as follows:

$k=A \exp \left(-E_{\mathrm{a}} / \mathrm{RT}\right)$ where $A$ is the pre-exponential factor, $E_{\mathrm{a}}$ is the activation energy and $R$ is the gas constant.

Solving Eq. (5) for $E_{\mathrm{a}}$ gives a theoretical value of $10.87 \mathrm{~kJ} \mathrm{~mol}^{-1}$ for an acidic hydrolysis of $\mathrm{NaBH}_{4}$. Comparing this value with the literature shows that it equals one eighth of a value $89 \mathrm{~kJ} \mathrm{~mol}^{-1}$ for a self-hydrolysis of unbuffered-unstabilized $20 \mathrm{wt} \% \mathrm{NaBH}_{4}$ solution [16], whereas it approximately equals ten times the value $1.24 \mathrm{~kJ} \mathrm{~mol}^{-1}$ obtained when applying sulfonated porous carbon catalyst [15].

It was observed at $3 \mathrm{M} \mathrm{HCl}$ that a maximum of $660 \mathrm{ml} /$ min and a minimum of $267 \mathrm{ml} / \mathrm{min} \mathrm{H}_{2}$ stream rate were obtained from 25 and $10 \mathrm{wt} \% \mathrm{NaBH}_{4}$, respectively, from applying a fuel solution rate of $0.97 \mathrm{ml} / \mathrm{min}$. However, a significant reduction in the hydrogen generation rate was observed when the molarity of $\mathrm{HCl}$ solution was increased to $4 \mathrm{M}$. After careful investigations, a modification was tried in which the peristaltic pumps were exchanged and consequently a highest hydrogen stream of $860 \mathrm{ml} / \mathrm{min}$ from $25 \mathrm{wt} \% \mathrm{NaBH}_{4}$ was obtained at a solution flowrate of $1.25 \mathrm{ml} / \mathrm{min}$. 
Table 2 Experimental results-25\% $\mathrm{NaBH}_{4}$ and $4 \mathrm{M} \mathrm{HCl}$

\begin{tabular}{|c|c|c|c|}
\hline \multirow[t]{2}{*}{ Amount of $\mathrm{NaBH}_{4}(\mathrm{~g})$} & 8.2 & \multirow[b]{2}{*}{ Solution wt $\%$} & \multirow[b]{2}{*}{25} \\
\hline & & & \\
\hline Amount of $\mathrm{NaOH}(\mathrm{g})$ & 0.3 & & \\
\hline \multirow[t]{2}{*}{ Mass of solution (g) } & 32.5 & & \\
\hline & & Density of solution $(\mathrm{g} / \mathrm{ml})$ & 1.00 \\
\hline Volume of solution (ml) & 32.4 & & \\
\hline Flow rate of $\mathrm{NaBH}_{4}(\mathrm{ml} / \mathrm{min})$ & 1.25 & Flow rate of $\mathrm{HCl}(\mathrm{ml} / \mathrm{min})$ & 0.97 \\
\hline Hydrogen generation rate & $\begin{array}{l}\text { Volume of } \\
\mathrm{H}_{2}(\mathrm{ml})\end{array}$ & Seconds & $\mathrm{ml} / \mathrm{min}$ \\
\hline Reading 1 & 250 & 17.47 & 858.6 \\
\hline Reading 2 & 250 & 17.61 & 851.7 \\
\hline Reading 3 & 250 & 17.35 & 864.5 \\
\hline Reading 4 & 250 & 17.59 & 852.7 \\
\hline Reading 5 & 250 & 17.18 & 873.1 \\
\hline Temp K & 328 & Mean HGR ml/min & 860.1 \\
\hline \multicolumn{4}{|l|}{ Using $1 \mathrm{~min}$ basis } \\
\hline \multicolumn{2}{|c|}{ Mass flow rate (density $\times$ flow rate of $\mathrm{NaBH}_{4}$ ) } & 1.253858 & \\
\hline \multicolumn{2}{|c|}{ Mass of $\mathrm{NaBH}_{4}$ (conc. of $\mathrm{NaBH}_{4} \times$ mass flow rate) } & 0.313465 & \\
\hline \multicolumn{2}{|c|}{ Mole of $\mathrm{NaBH}_{4}$ (mass of $\mathrm{NaBH}_{4} / 37.8$ ) } & 0.008293 & \\
\hline \multicolumn{2}{|c|}{ Mole of $\mathrm{H}_{2}\left(\right.$ mole of $\left.\mathrm{NaBH}_{4} \times 4\right)$} & 0.033171 & \\
\hline \multicolumn{2}{|c|}{ Theoretical volume of hydrogen $(\mathrm{ml} / \mathrm{min})$} & 873.76 & \\
\hline \multicolumn{2}{|c|}{ Actual volume of hydrogen (ml/min) } & 860.16 & \\
\hline \multicolumn{2}{|l|}{ Conversion efficiency } & $98 \%$ & \\
\hline \multicolumn{2}{|l|}{ Molar HGR } & 0.032954 & \\
\hline \multicolumn{2}{|l|}{ Ampere (A) } & 105.9887 & \\
\hline \multicolumn{2}{|l|}{ Watt (W) } & 74.19 & \\
\hline \multicolumn{2}{|l|}{ Product $\mathrm{pH}$} & 8-light basic & \\
\hline
\end{tabular}

Somehow, researchers concluded that the hydrogen generation rate proportionally increases with an increase of $\mathrm{NaBH}_{4}$ concentration up to a certain point. After that point, a reduction in the hydrogen generation rate was reported in the work of [9, 14], and [17].

In the current study, a continuous increase in the hydrogen generation rate was observed with a parallel increase in $\mathrm{NaBH}_{4}$ concentration when using acidic scheme and applying $\mathrm{HCl}$ as an acid accelerator, as presented in Fig. 2. This result is partially related to the hydrogen storage capacity which increases theoretically with a parallel increase in $\mathrm{NaBH}_{4}$ concentration fed to the system. Additional reason could be a high conversion which occurred as a result of an efficient direct contact between fuel solution and acidic accelerator through a tee junction. This result is in agreement with the findings of several researchers $[3,10,18]$. They concluded that using $\mathrm{NaBH}_{4}$ in a solid form, while being injected through aqueous acidified water, is more efficient than alkaline stabilized form. They showed that an acidic scheme offers to pack more hydrogen per unit volume of hydrogen generator, while the mode of contact between two reacting species would become much easier.
Other important observation was an increase in the hydrogen generation rate upon parallel increases in fuel concentration and feeding rate. This phenomenon has also been observed by Kim et al. [3] up to such extent after which a decrease was denoted in the hydrogen generation rate and interpreted due to a shortage in the contact time with the catalyst. Other researchers Subramanian and Javed [18] and Kim et al. [3] applied controlled injections of fuel solution into the hydrogen generator via syringe and piezoelectric pumps, respectively, and indicated that better hydrogen generation control was achieved. This clearly illustrates that hydrogen production from $\mathrm{NaBH}_{4}$ using $\mathrm{HCl}$ accelerator is highly controllable. Thereby, any desired hydrogen generation rate could be obtained by increasing or decreasing solution flow rates. This identity is so beneficial for onboard fuel cell system applications and ultimately the abovementioned results indicate that a possible amelioration in the hydrogen generation rate could be achieved by applying higher $\mathrm{NaBH}_{4}$ concentrations and using the proposed scheme as compared with the data reported in the literature obtained via catalytic scheme.

With regards to the acid applied, the literature reported that all acids facilitate an increase in the hydrogen yield 
Table 3 Experimental results-30\% $\mathrm{NaBH}_{4}$ and $3 \mathrm{M} \mathrm{HCl}$

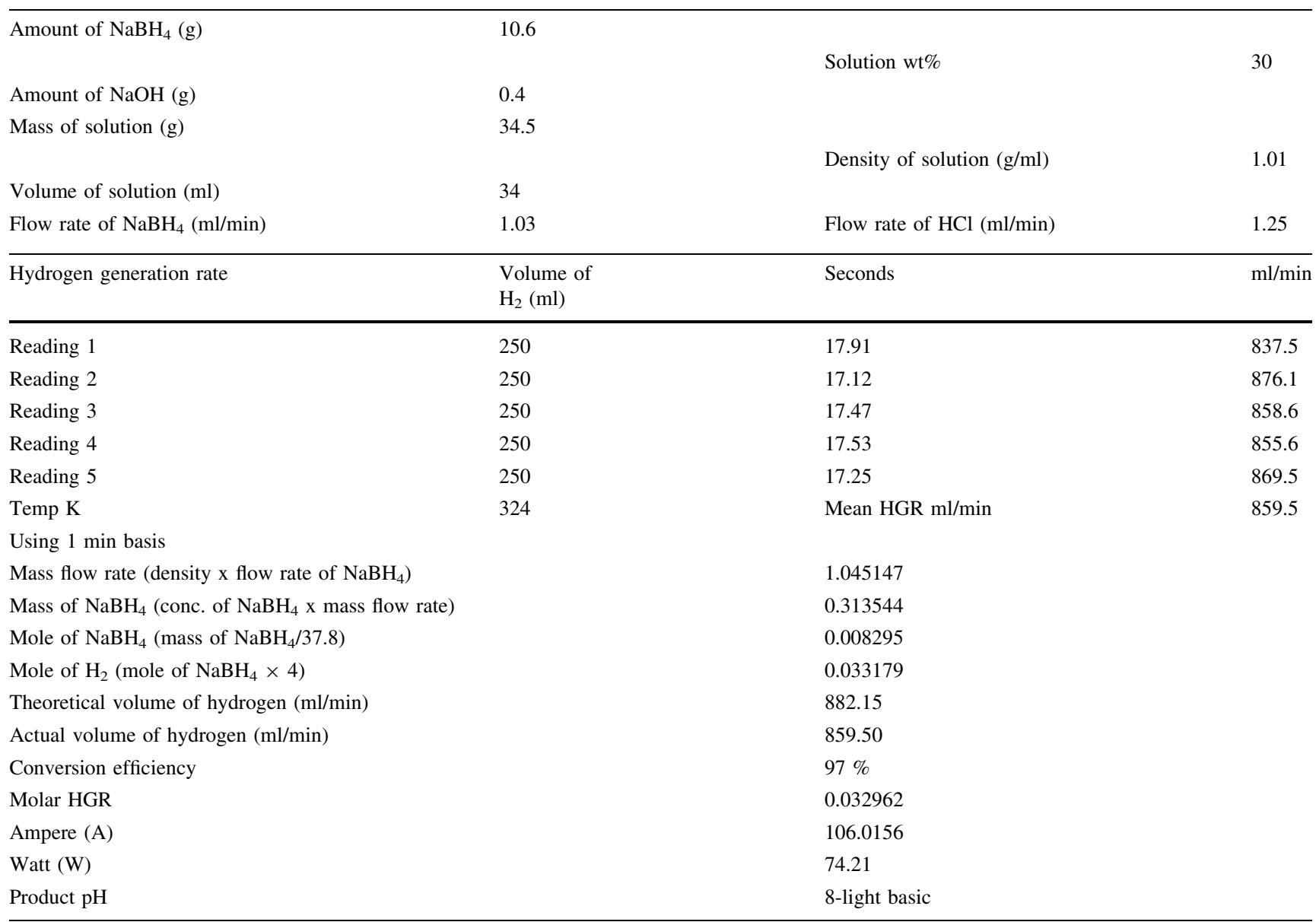

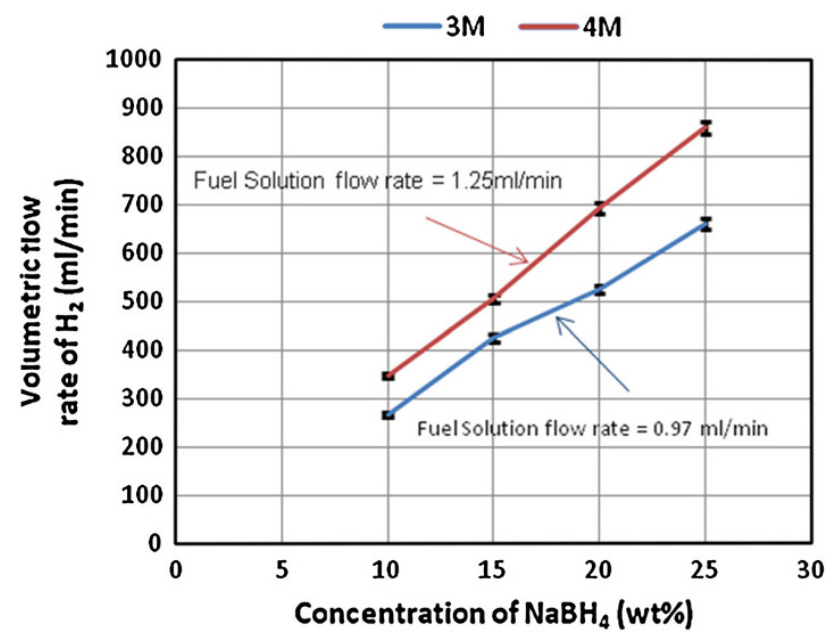

Fig. 2 Effect of $\mathrm{NaBH}_{4}$ concentrations on the hydrogen stream generation rate at different fuel solution flow rates and accelerator concentrations. $\mathrm{HCl}$ flow rates were $0.97 \mathrm{ml} / \mathrm{min}$ in case of $4 \mathrm{M}$ and $1.25 \mathrm{ml} / \mathrm{min}$ in case of $3 \mathrm{M}$

with an increase in the acid concentration. Nonetheless, a significant drop was observed with an addition of nitric acid and phosphoric acid as compared to the hydrochloric acid and sulphuric acid. Eventually, three acids were highly recommended with their ideal concentrations which include $\mathrm{HCl}$ at $3 \mathrm{~N}$ (yield $97 \%), \mathrm{H}_{2} \mathrm{SO}_{4}$ at $3 \mathrm{~N}(96 \%$ yield) and $\mathrm{HCOOH}$ at $12 \mathrm{~N}$ (87\% yield), [13]. More concise, Demirci et al. [11] specified $\mathrm{HCl}$ as an acid of choice for catalysing $\mathrm{NaBH}_{4}$ hydrolysis with very high hydrogen generation rate.

$\mathrm{HCl}$ concentrations of 3 and $4 \mathrm{M}$ were applied in the current research. Both of them showed some exceptional results and durability in terms of reaction and by-products generation. However, a clear difference was observed in the reactivity as $3 \mathrm{M}$ solution was quite favourable yet gave maximum conversion efficiency and the reaction was highly controllable. On the other side, $4 \mathrm{M}$ solution showed a strong and vigorous reaction with $\mathrm{NaBH}_{4}$ which is believed to be due to $\mathrm{HCl}$ reactivity. In terms of conversion efficiency and hydrogen generation rate, $\mathrm{HCl}$ stream of $4 \mathrm{M}$ concentration was found less competitive even after pumps exchanged. Accordingly, $3 \mathrm{M}$ of $\mathrm{HCl}$ is found to be an optimal concentration in case of low $\mathrm{NaBH}_{4}$ concentration, whilst $4 \mathrm{M}$ concentration is recommended for high $\mathrm{NaBH}_{4}$ concentration. 
The efficiency of hydrogen generation was calculated according to the following formula:

$\eta=\frac{V \text { actual }}{V \text { theoretical }} \times 100$

where;

$V_{\text {actual }}=$ the actual hydrogen volume measured via water displacement method.

$V_{\text {theoretical }}=$ volume of hydrogen estimated theoretically according to Eq. (2), where $4 \mathrm{~mol}$ of hydrogen is generated from decomposing $1 \mathrm{~mol}$ of $\mathrm{NaBH}_{4}$.

Conversion efficiency is a vital parameter behind successful generation of hydrogen gas. This efficiency shows the amount of fuel which is totally converted into its byproducts during specific time duration. In this study, a maximum and a minimum conversion efficiency of fuel solution was obtained as 99 and $98 \%$ from applying 3 and $4 \mathrm{M} \mathrm{HCl}$ solutions, respectively.

The application of two stages gas liquid separator (GLS) in the current system has proved useful in terms of accomplishing high conversion, where any unspent fuel (not converted in the tee junction) is forcefully converted in the product collector, 1st GLS, and results in liberating rest of hydrogen gas. Eventually, $\mathrm{NaBH}_{4}$ fuel was fully converted into by-products after few minutes of reaction completion. Ultimately, 2nd GLS accomplished the removal of any hydrolysed mist coming with the generated hydrogen stream, which was mainly due to a high reaction temperature.

The estimated hydrogen generation efficiency through the experiments of first case study is shown in Fig. 3 .

By applying the proposed experimental configuration, a hydrogen gas stream of higher flow rates was generated with a maximum conversion efficiency of $\mathrm{NaBH}_{4}$.

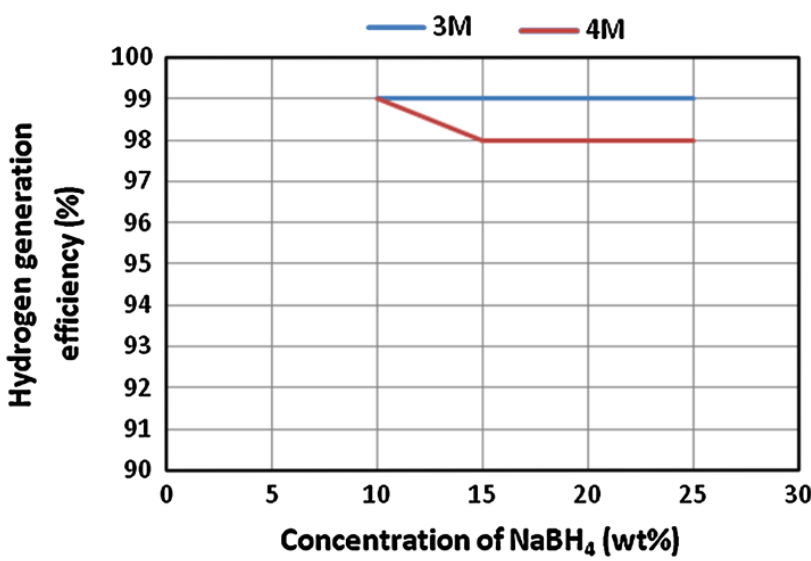

Fig. 3 Effect of $\mathrm{NaBH}_{4}$ concentration on the hydrogen generation efficiency. $\mathrm{HCl}$ flow rates were $0.97 \mathrm{ml} / \mathrm{min}$ in case of $4 \mathrm{M}$ and $1.25 \mathrm{ml} / \mathrm{min}$ in case of $3 \mathrm{M} . \mathrm{NaBH}_{4}$ solution flow rates were $1.25 \mathrm{ml} /$ $\min$ in case of $4 \mathrm{M} \mathrm{HCl}$ and $0.97 \mathrm{ml} / \mathrm{min}$ in case of $3 \mathrm{M} \mathrm{HCl}$
It should be noted that the reaction temperature is a vital parameter that affects the reaction rate and generation efficiency. Retnamma et al. [16] reported that the reaction rate increases with both temperature and initial $\mathrm{NaBH}_{4}$ concentration for a fixed $\mathrm{NaBH}_{4}$ conversion and decreases with increase in $\mathrm{NaBH}_{4}$ conversion for a fixed temperature and initial $\mathrm{NaBH}_{4}$ concentration for a self $\mathrm{NaBH}_{4}$ hydrolysis process. The temperature effect was also investigated by many researchers in which a positive effect was indicated when increasing the solution temperature for the catalytic hydrolysis of $\mathrm{NaBH}_{4}$. In the current work, the efforts were dedicated to apply the acidic hydrolysis at ambient temperature to adopt the system for mobile fuel cells. Hence, the contact between fuel solution and the $\mathrm{HCl}$ stream was conducted via a tee junction at ambient temperature $\left(\approx 20{ }^{\circ} \mathrm{C}\right)$, whereas the product solution was directed to a GLS. An increase in the aqueous product temperature (collected in the GLS) was observed, where the temperature was measured in the range (305-328 K); Tables 1, 2, and 3, for several case studies applied in this research. The product temperature has increased with an increase in both $\mathrm{NaBH}_{4}$ and $\mathrm{HCl}$ concentration in the system. The recorded data indicated a reasonable increase in the temperature which can be treated easily for mobile fuel cell applications.

A power analysis was conducted based on the determined hydrogen flow rate. It is known that 2 mol of electrons (equivalent to $12.04 \times 10^{23}$ electrons) is released at the anode for each mole of hydrogen entering a polymer electrolyte membrane (PEM) fuel cell, according to the following formula.

$\mathrm{H}_{2} \rightarrow 2 \mathrm{H}^{+}+2 \mathrm{e}^{-}$

Since $1 \mathrm{~A}$ is equivalent to $6.25 \times 10^{18}$ electrons per second, therefore $0.5 \times 10^{-5} \mathrm{~mol} / \mathrm{s}$ or $3 \times 10^{-4} \mathrm{~mol} / \mathrm{min}$ of hydrogen is required for each ampere generated in PEM fuel cell. Accordingly, the power of PEM working at $700 \mathrm{mV}$ can be estimated as follows [19]:

$P(\mathrm{~W})=I(\mathrm{~A}) \times 0.7 V(\mathrm{~V}) \times$ efficiency

It was observed that in addition to the hydrogen generation rate, the power output was also increased when increasing $\mathrm{NaBH}_{4}$ concentration. Highest power output was estimated to be $74 \mathrm{~W} / \mathrm{min}$ with $860 \mathrm{ml} / \mathrm{min}$ of hydrogen flow rate when applying $25 \mathrm{wt} \%$ of $\mathrm{NaBH}_{4}$ fuel solution. Lowest power output of $24 \mathrm{~W} / \mathrm{min}$ with hydrogen flow rate of $268 \mathrm{ml} / \mathrm{min}$ was estimated when applying $10 \mathrm{wt} \%$ of $\mathrm{NaBH}_{4}$ fuel solution. Figure 4 illustrates the increase in the estimated power with an increase of $\mathrm{NaBH}_{4}$ concentration at 3 and $4 \mathrm{M} \mathrm{HCl}$.

Purity of the generated hydrogen stream was checked upon analysing several samples, collected from the outlet of 2nd GLS using a gas sampler, applying GC method. 
Figure 5 shows analysis results of one collected sample. Oxygen and nitrogen peaks can be observed at low intensity and attributed to penetration of air into gas sampler during sample collection.

GC analysis results are shown in Table 4, where 97 wt $\%$ was produced from two samples injection, and indicates a high convergence to the data estimated from previous analysis based on applying a water displacement method.

As it was essential to verify system performance at higher $\mathrm{NaBH}_{4}$, a $30 \mathrm{wt} \% \mathrm{NaBH}_{4}$ was injected to the

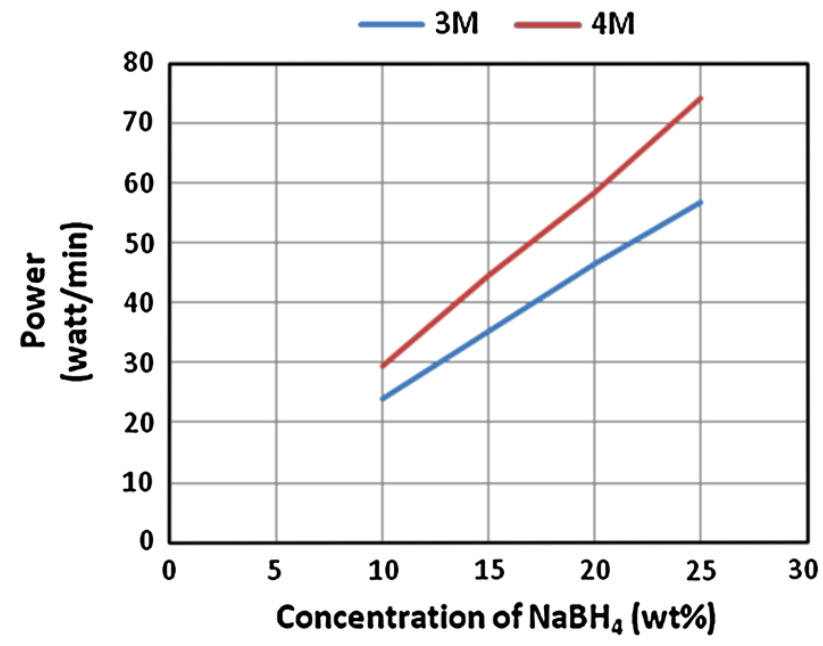

Fig. 4 Estimated power output from PEM fuel cell at different concentrations of $\mathrm{NaBH}_{4}$ and $\mathrm{HCl}$. $\mathrm{HCl}$ flow rates were $0.97 \mathrm{ml} / \mathrm{min}$ in case of $4 \mathrm{M}$ and $1.25 \mathrm{ml} / \mathrm{min}$ in case of $3 \mathrm{M}$. NaBH 4 solution flow rates were $1.25 \mathrm{ml} / \mathrm{min}$ in case of $4 \mathrm{M} \mathrm{HCl}$ and $0.97 \mathrm{ml} / \mathrm{min}$ in case of $3 \mathrm{M} \mathrm{HCl}$ system in the second case study. The selection of this concentration was to meet the US DOE targets for 2015 for onboard hydrogen storage capacity which equals $5.5 \mathrm{wt} \%$ gravimetrically. Gervasio et al. [20] reported that a $100 \%$ conversion efficiency was accomplished from $30 \mathrm{wt} \%$ of $\mathrm{NaBH}_{4}$ through a catalytic scheme using $\mathrm{Ru}$ catalyst. The exceptional result achieved might be related to different reasons such as excess amount of catalysts used in their reactor, which is not practical for vehicular fuel cell system application.

Although a higher generation efficiency was achieved (>99 \%) when $30 \mathrm{wt} \%$ of $\mathrm{NaBH}_{4}$ was applied using the same conditions of the first case study, an appearance of precipitated materials (crystals of sodium borates) in the collector (1st GLS) was observed. These precipitated materials also appeared when a lower $\mathrm{NaBH}_{4}$, up to $25 \mathrm{wt} \%$, was used but with very low quantity. Therefore, several parameters were explored aiming to reduce crystals formation and their precipitation. Ultimately, $\mathrm{NaBH}_{4}$ fuel solution injection rate was found to be the main reason; accordingly, a new peristaltic pump of $1.03 \mathrm{ml} / \mathrm{min}$ (calibrated flow rate) was applied instead. In consequence, the hydrogen generation efficiency was reduced to $98 \%$ but still concurs the 2015 target, and the precipitation was stopped.

Table 4 Sample of a GC analysis

\begin{tabular}{lrrr}
\hline Measurements & Pure $\mathrm{H}_{2}$ & Injection 1 & Injection 2 \\
\hline Area (counts) & $3,428,887$ & $3,250,660$ & $3,126,828$ \\
Concentration (wt\%) & 100 & 97 & 97 \\
\hline
\end{tabular}

Fig. 5 A chromatograph for a collected sample of generated hydrogen stream from 2nd GLS upon injecting $25 \mathrm{wt} \% \mathrm{NaBH}_{4}$ and $3 \mathrm{M} \mathrm{HCl}$ at 0.97 and $1.25 \mathrm{ml} / \mathrm{min}$, respectively

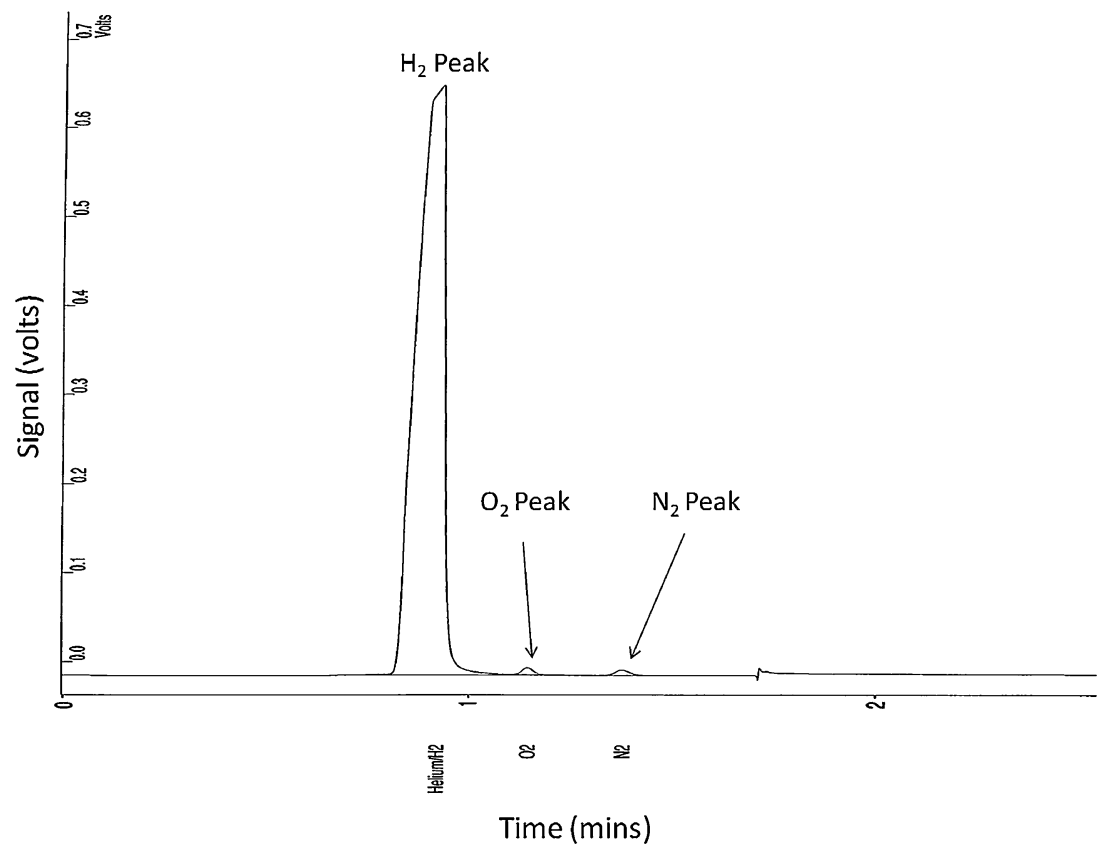


It can be observed that the estimated hydrogen flow rate $(863 \mathrm{ml} / \mathrm{min})$ generated from applying $30 \% \mathrm{NaBH}_{4}$ concentration at $1.03 \mathrm{ml} / \mathrm{min}$ fuel solution and $3 \mathrm{M} \mathrm{HCl}$ was equivalent to a rate $(860 \mathrm{ml} / \mathrm{min})$ generated from applying $25 \% \mathrm{NaBH}_{4}$ at $1.25 \mathrm{ml} / \mathrm{min}$ and $3 \mathrm{M} \mathrm{HCl}$, which means that $74 \mathrm{~W} / \mathrm{min}(4.44 \mathrm{kWh})$ is produced from both cases. However, use of lower flow rate of fuel solution is indeed more economical at large-scale systems and also advantageous in terms of lowering liberated heat and by-products crystallization and precipitation.

\section{Conclusions}

Two case studies were conducted to investigate feasibility of using $\mathrm{HCl}$ scheme as an alternative to a catalytic scheme for hydrogen generation from sodium borohydride system serving vehicular fuel cells. The main objective was to meet the DOE 2015 onboard hydrogen storage target (5.5 wt \%). Exceptional results showed that onboard mixing of fuel and acidic streams in the proposed system of two gas-liquid separators proved useful for higher conversion efficiency and system performance. $98 \%$ conversion efficiency without any sodium borates precipitation was achievable upon optimizing $\mathrm{NaBH}_{4}$ fuel solution flow rate. Hence, a hydrogen generation rate of $863 \mathrm{ml} / \mathrm{min}$ was obtained from applying $30 \mathrm{wt} \% \mathrm{NaBH}_{4}$ at $1.03 \mathrm{ml} / \mathrm{min}$ and $3 \mathrm{M} \mathrm{HCl}$ at $0.97 \mathrm{ml} / \mathrm{min}$, achieving $4.44 \mathrm{kWh}$ of power. Other important feature observed was reaction controllability, where it can be stopped by addition of alkaline medium (e.g. sodium hydroxide) or accelerated by adding acid.

Open Access This article is distributed under the terms of the Creative Commons Attribution License which permits any use, distribution, and reproduction in any medium, provided the original author(s) and the source are credited.

\section{References}

1. Hsu SE, Beibutian VM, Yeh MT (2001) Preparation of hydrogen storage alloys for applications of hydrogen storage and transportation. J Alloy Compd 330:882-885

2. Kikukawa S (2007) Consequence analysis and safety verification of hydrogen fuelling stations using CFD simulation. Int J Hydrogen Energy 33:1425-1434

3. Kim HJ et al (2010) Hydrogen generation from aqueous acidcatalyzed hydrolysis of sodium borohydride. Int $\mathbf{J}$ Hydrogen Energy 35:12239-12245
4. Demirci UB, Akdim O, Andrieux J, Hannauer J, Chamoun R, Miele P (2010) Sodium borohydride hydrolysis as hydrogen generator: issues, state of the art and applicability upstream from a fuel cell. Fuel Cells 10(3):335-350

5. George L, Saxena SK (2010) Structural stability of metal hydrides, alanates and borohydrides of alkali and alkali-earth elements: a review. Int J Hydrogen Energy 35:5454-5470

6. US department of energy hydrogen program: Go/No-Go Recommendation for sodium borohydride for on-board vehicular hydrogen storage-independent review, National Renewable Energy Laboratory (2007). Last accessed 24 Dec 2013 on: http:// www.hydrogen.energy.gov/pdfs/42220.pdf

7. Schlesinger HI et al (1953) Sodium borohydride its hydrolysis and its use as a reducing agent and in the generation of hydrogen. J Chem Soc 7:215-219

8. Amendola SC et al (2000) A safe, portable, hydrogen gas generator using aqueous borohydride solution and $\mathrm{Ru}$ catalyst. Int $\mathrm{J}$ Hydrogen Energy 25:969-975

9. Liang Y et al (2010) Hydrogen generation from sodium borohydride solution using a ruthenium supported on graphite catalyst. Int J Hydrogen Energy 35:3023-3028

10. Demirci UB, Miele P (2008) Sodium tetrahydroborate as energy/ hydrogen carrier, its history. C R Chim 12:943-950

11. Demirci UB et al (2009) Acetic acid, a relatively green single-use catalyst for hydrogen generation from sodium borohydride. Int $\mathrm{J}$ Hydrogen Energy 34:7231-7238

12. Demirci UB et al (2009) Highly efficient acid-treated cobalt catalyst for hydrogen generation from $\mathrm{NaBH}_{4}$ hydrolysis. Int $\mathrm{J}$ Hydrogen Energy 34:4780-4787

13. Subramanian V, Murugesan S (2009) Effects of acid accelerators on hydrogen generation from solid sodium borohydride using small scale devices. J Power Sources 187:216-223

14. Abdul-Majeed WS, Serdaroglu GM, Zimmerman WB (2012) Application of liquid nitrogen cold trap for purification of hydrogen gas stream generated from $\mathrm{NaBH}_{4}$. J Chem Chem Eng 6(5):425-434

15. Shokrolahi A, Zali A, Pouretedal HR (2012) Hydrogen generation from hydrolysis of sodium borohydride using sulfonated porous carbon as reagent/catalyst. Iran J Catal 2(4):179-184

16. Retnamma et al. (2011) Kinetics of self-hydrolysis of concentrated sodium borohydride solutions at high temperatures, International Congress on Energy (2011 AIChE Annual Meeting). Last accessed 23 Dec 2013 on: http://repositorio.lneg.pt/bitstream/10400.9/1429/ 1/Rajasree\%20et\%20al_\%20AIChE_2011.pdf

17. Pinto AM et al (2006) Hydrogen generation and storage from hydrolysis of sodium borohydride in batch reactors. Int $\mathrm{J}$ Hydrogen Energy 3:1341-1347

18. Javed U, Subramanian V (2008) Hydrogen generation using a borohydride-based semi-continuous milli-scale reactor: effects of physicochemical parameters on hydrogen yield. Energy Fuels 23:408-413

19. Kojima Y et al (2004) Development of $10 \mathrm{~kW}$-scale hydrogen generator using chemical hydride. J Power Sources 125:22-26

20. Gervasio D et al (2005) Room temperature micro-hydrogengenerator. J Power Sources 149:15-21 